\title{
Obtaining Audit Evidence for Assessing Companies' Ability to Continue as a Going Concern, Using Duration Models
}

\author{
Marilena Mironiuc, loan-Bogdan Robu and Mihai Carp
}

Alexandru Ioan Cuza University of Iaşi, Romania

\begin{abstract}
According to The International Standards on Auditing, the purpose of the auditor in an audit engagement is to express an independent, objective and a professional opinion regarding the accuracy of the financial statements of the companies audited. During his mission, the auditors must also assess the company's ability to continue as a going concern, with a major impact on the preparation and the quality of financial statements that are reported. To support his opinion, regarding the hypothesis of going concern, the auditor must obtain sufficient and appropriate audit evidence, and perform the necessary audit procedures. For that, analytical procedures ensure a series of comparative information at the level of analyzed periods or branch, useful to the auditor in the audit engagement. The present study aims to obtain a deterministic model based on duration models, for assessing the audited companies' ability to continue as a going concern. The research results are useful to the auditor in the assessment of the audited company's compliance with the going concern assumption, in preparation of financial statements. The analysis was performed on a sample of 77 companies quoted on the Bucharest Stock Exchange that were subject to the insolvency risk, in the period 2008-2011. To obtain the research results, data were treated with statistical software SPSS 19.0.
\end{abstract}

Keywords: duration models, audit evidence, going concern, analytical procedures, insolvency risk.

\section{Introduction}

Appeared as a factor of correcting the imbalance created between the financial and the real component (of production and of goods transfer) of economic life, the economic-financial crisis has required companies to make significant adjustments both at the level of rendering the activity more efficient and at the level of the business structure. Motivated by an exaggerated optimism concerning the economic growth trends, numerous entities have neglected to make consolidated business development plans, venturing into drawing strategies based exclusively on the optimistic side, the one in which the potential gains became certain, neglecting the incidence of risk on any other economic approach, as well as the measures to minimize it.

Under these circumstances, the restrictions felt both at the level of insuring the financial resources and at that of placing the resulting goods on the market, generated by the instability that characterizes the current economic environment, have determined the occurrence of intense changes in the autochthonous business environment. Many companies have seen themselves forced to reduce, reorganize, or terminate their activity. The uncertainties and mutations in the economic environment determine the confrontation of the investment process with numerous dilemmas, and solving the conditions the

Copyright (C) 2012 Marilena Mironiuc, Ioan-Bogdan Robu and Mihai Carp. This is an open access article distributed under the Creative Commons Attribution License unported 3.0, which permits unrestricted use, distribution, and reproduction in any medium, provided that original work is properly cited. Contact author: Marilena Mironiuc E-mail: marilena@uaic.ro 
opportunity and profitability of the adopted decisions.

Both the investor, as owner of available capital, and companies, as carriers of the demand of such resources, are interested in building a relationship based on a faithful, real image on the financial position and performance, provided through financial statements and certified by issuing a qualified opinion by the auditors. The partners are concerned both with events that took place in the past and with the perspective of performing and developing the business. If the organizational characteristics concerning the past can be rigorously evaluated and supported, through and based on a number of procedures and information, forecasting the direction in which the company's activity will evolve requires deep analyses and judgments that correlate data specific to the internal environment with those generated by the perspectives of the activity field and of the general economic environment.

In this sense, the present article aims to analyze the impact of the financial crisis on the ability to survive of the companies, identifying the factors that influence the application of the going concern principle, as well as quantifying their influence in order to obtain the audit evidence in the financial audit mission. The study was performed at the level of companies quoted in the Bucharest Stock Exchange (BSE), for the period 2008-2011.

\section{Literature Review}

International Accounting Standard (IAS) 1 - Presentation of Financial Statements states that when drawing the financial statements, the management must evaluate the ability of the company to continue its activity. Financial statements must be drawn based on the continuity of activity, except the case when the management intends to either dissolve the company or terminate its activity, or it has no other alternative (IASB, 2009).

Complementary to the company's management, the role of the financial auditor, in what concerns certifying the information synthesized in financial statements and their manner of presentation, is intensified, acquiring predictive valences by testing the application of the going concern principle at the company level. Actually, International Standard on Auditing (ISA) 520 - Analytical Procedures (IFAC, 2009) claims that when planning and performing audit procedures, as well as when evaluating their results, the auditor must take into account the appropriateness of the usage by the management of the going concern principle, which lies at the basis of drawing the financial statements.

As stipulated in ISA 315 - Understanding the Entity and its Environment and Assessing the Risks of Material Misstatement, the auditor must obtain knowledge of the entity and of its environment, including its internal control, enough to identify and evaluate the risk of existence of significant distortions of financial statements (IFAC, 2009).

According to ISA 520 (IFAC, 2009), the auditor must apply analytical procedures for evaluating risk in order to reach an understanding of the entity and of its environment. Applying the analytical procedures may reveal some aspects of the entity that the auditor was not aware of, and which will help them evaluate the risk of significant distortion in order to determine the nature, duration, and length of other supplementary audit procedures.

\section{The Auditor's Responsibility in Assessing Companies' Ability to Continue as a Going Concern}

Seen as a postulate associated exclusively to accounting, the going concern assumption requires managers to prepare the financial statements starting from the premise that the audited company will continue its activity within a predictable time horizon, except the case when the management wishes to dissolve the company or terminate its activity (IASB, 2009). According to ISA 570 (IFAC, 2009), in the evaluation of the company's ability to continue its activity, managers must 
evaluate the subsequent result to the events or conditions that are inherently uncertain. This evaluation is based on the degree of uncertainty associated with the subsequent events, on the availability of the information at the moment of the judgment, on the company's dimension and complexity, on the nature and state of its activity, as well as on the extent to which it is affected by external factors (Braiotta, 2010).

In accordance with ISA, Soltani (2007) considers that within a financial audit mission, the main purpose of the auditor is to formulate a professional, objective, and independent opinion on the accuracy of the financial statements under the most significant aspects, according to the accounting reference to which they relate. In their study, Herborn et al. (2007) stress out the importance of the audit opinion through the added value it creates and that contributes to the development of financial markets.

The quality of the financial accounting information is one of the stakeholders' priorities, influencing their strategic decisions (Bessell et al., 2003), as well as a desideratum of financial markets (Kausar et al., 2009), the performance criterion of accounting being represented by the faithful image, defined as the extent to which the economic-financial reality is objectively rendered, in a complete and pertinent manner of the economic facts and processes expressed in a monetary gauge (Vrentzou, 2011). Seen either as a fundamental objective in sense of continental doctrine, or as an essential principle in the Anglo-Saxon view, the faithful image aims to insure a balance between honesty and regularity of reporting. Although tempted not to comply with the application of going concern, according to IAS-IFRS, the quality of the financial accounting information is insured by the mechanisms of corporate governance as well by issuing the audit report (Uang et al., 2006).

The financial auditor must analyze the appropriateness of the usage by management of the going concern (Hayes et al., 2005), and in case they have substantial doubts on the company's ability to circumscribe to this principle, the auditor must present their explicit opinion concerning the compliance with this principle (Bhimani et al., 2009). ISA 570 Going Concern stipulates that a guarantee for complying with this principle is the absence of any reference in the audit report concerning the uncertainty related to the going concern (Elliot et al., 2006).

In the financial audit mission, Porter et al. (2003) support the need for the auditor to question the management in what concerns the events and risks related to the company's activity, for their exhaustive understanding, as well as in order to be able to identify the factors that may significantly question the ability to continue its activity, beyond the predicted period. The appropriate presentation of this principle in the financial statements leads the auditor to the possibility to express their unreserved opinion, and in case that supplementary clues or explanations exist in the notes to the financial statements, they will modify the audit report by adding a paragraph that stresses the existence of a significant uncertainty that may question the entity's ability to continue its activity (IFAC, 2009). In case the financial statements do not make any appropriate presentation, the auditor must express a reserved or contrary, in compliance with ISA 700 Forming an Opinion and Reporting on Financial Statements. Additionally, the audit report must include an express reference to the fact that there is a significant uncertainty that may question the entity's ability to continue its activity (Hayes et al., 2005).

In his work, in compliance with the professional standards (IFAC, 2009), Soltani (2003) mentions a series of financial and operational elements that may signal certain inadequacies in complying with the going concern. Based on an idea suggested by Matsumura et al. (1997) in evaluating the compliance with the going concern, the auditor will take into account as signal indicators the high level of debt, the due date of loans that cannot be 
paid back or evened out, the main creditor's drawing back their financial support and the impossibility of external funding, negative cash flows and operational results, unfavorable key financial indicators, missing the payment of dividends, losing key management members or the market share, difficulties with the work force or possible lawsuits. Last but not least, of the significant factors that contribute to complying with the going concern in financial reporting, Franks and Lóránth (2010) give special attention to the bankruptcy procedure generated by the company's becoming insolvent, and Bhimani et al. (2009) consider it essential to issue an opinion on Going Concern in order to evaluate the insolvency risk based on the financial indicators in the financial statements.

\section{Elements that may Signal the Presence of the Insolvency Risk in the Going Concern Assessment}

The natural state in which a company performs its activity is that in which going concern is not affected and is a vital objective. However, under the influence of factors in the economic environment and of the internal policy, it is not seldom that companies are forced to face a situation in which complying with the mentioned principle is questioned. Becoming insolvent, as an effect of infringing the going concern assumption, requires decisions and solutions compatible with the real situation of the entity. The dilemma in which the economic agent finds himself and from which he must emerge is represented by the opportunity and the possibility to reorganize the activity or to launch the bankruptcy process.

The objectives of reorganizations are to eliminate the causes that have triggered insolvency, to close deals with the creditors, in order to insure that the company is kept in business. This way, the company is given an opportunity to improve and continue its operations, using specific mechanisms with the purpose of avoiding bankruptcy (Chitnomrath et al., 2011).
Under these circumstances, shaping a correct image of the insolvency risks that mark the economic environment where the audited company performs its activity, the factors that generate such conditions, is a necessary basis for issuing a correct audit opinion. Correlating the companies' ability to continue their activity with their own financial and non-financial factors may provide relevant clues concerning the environmental risk.

Complementing the collected information, specific to the audit approach, with data on the common economic environment is a key element that insures the appropriateness and sufficiency of the audit evidence, as an essential condition for the process of certifying the financial statements.

The evaluation of the impact of financial and non-financial indicators on the companies' ability to survive, in conditions of economic instability, cannot be performed individually. They act together on companies, influencing and conditioning each other.

The activity field, the specific area where the entity acts transmits its influence on its destiny. In the turmoil of economic imbalances, caused by the crises in the field, certain activity branches see their performance and stability affected to various extents. Bandyopadhyay (2006), Ooghe and De Prijcker (2008) state that the sector to which the company belongs may influence its performance as well as its ability to continue its activity. The authors draw models for predicting bankruptcy, identifying as determinant factors for this phenomenon, besides the mentioned element, the size of the assets, the age and size of the company.

Together with internal factors, such as the degree of indebtedness, the asset immobilization ratio, the delay for debt collection, the specificity of the company determines the way it must carefully take in order to overcome critical periods. 
In this sense, a significant degree of indebtedness, where total debts are higher than the double of the shareholders' equity and if the latter is not supported by healthy investment projects, debts erode, through the generated financial expenses, the profitability of the basic asset. This determines the occurrence of negative financial results, and their succession over a series of fiscal years places a doubt on the company's ability to continue its activity.

Also, a high debt level limits the company's ability to pay dividends, since the available cash flow is used to pay back the credits and their associated costs (Zaher, 2010).

In the same direction, Philosophov and Philosophov (2005) make a study at the level of the American companies that went bankrupt within a certain time period, trying to draw a model for forecasting the occurrence of the risk of bankruptcy, where they show that ceasing the company's activity decisively depends on the financial structure of the company, synthesized through the financial leverage, as well as on the characteristics of the various categories of capital involved, respectively their cost and due date.

A ratio of immobilization of the asset over the average limit of the activity field of the company determines issues in its ability to adapt to the changes in the business environment, which are frequent in periods of crisis because of the more difficult transformation of this category of assets into liquidity and of the issues that may occur when the company has to reconsider its activity field (Mironiuc, 2009).

Krause (2006) notices the presence of peripheral assets, which the entity does not need in order to perform its daily operations and whose release does not determine present of future losses for the company. Making such acquisitions, however, generates opportunity costs that diminish the financial performance of the company, weakening at the same time its stability and growth perspectives.
Another element that becomes an indicator of the risk of insolvency can be considered the debt collection delay. Although this measure is analyzed in correlation with the dimension of the term for paying the suppliers, its exceeding an average level for the branch or increasing from a period to another may signal the imminence of side slips in what concerns the liquidity of the company. The latter will encounter difficulties in paying its short term debts on time, which will generate repercussions on the well development of the operational cycle, respectively of going concern. In this sense, Liou and Yang (2008) recommend using in models for predicting the risk of bankruptcy of indicators concerning cash resources and stocks as essential variables, complementary to financial ratios.

An adverse liquidity ratio increases the companies' difficulties in what concerns preserving their clients. The effect of the loss of these partners has a negative action on the operational process and, together with the specificity of the activity field (especially when long-term contracts are used), may determine the occurrence of the risk of bankruptcy (Ooghe and De Prijcker, 2008).

Schroeder (2009), studies "financial fragility" as a process that results in financial instability, respectively insolvency, correlating the occurrence of this phenomenon with the characteristics of the economic and political environment specific to the entities. Overcoming this problem is seen only from the perspective of the ability to detect it in time, in order to create the necessary time interval for taking compensatory measures.

Besides these elements that show the uncertainties connected to the future of the company, ISA 570 also notices a series of indicators of a possible termination of activity: approaching the deadline for fixed term loans with no other realistic perspectives to renew them or pay them back, or excessively relying on short-term loans for funding long-term assets, 
Which are signs of withdrawal of the financial support by debtors and other creditors, switching credit transactions to transactions payable upon supplier delivery, etc. (IFAC, 2009).

All these signals, identified through analytical procedures, come to complete the information load that represents the audit evidence that the specialist in this field, the auditor, uses in their professional approach.

\section{Obtaining Audit Evidence for the Going Concern Assessment}

According to ISA 500 - Audit evidence, Hayes et al.(2005) define audit evidence as the set of information used by the auditor to draw conclusions that support their opinion. Audit evidence include both information contained in the accounting records on which financial statements are drawn (IFAC, 2009), and other additional information mentioned in USGAAS (United States Generally Accepted Auditing Standards). Therefore, the Statement on Auditing Standard - SAS 106: Audit Evidence completes ISA 500 in paragraph 5, point c), with the following: other information that can be used by the auditor in obtaining audit evidence may come from previous missions, clients' declarations, analysts' reports, control manuals, and from the financial markets (Bragg, 2010).

Performing the financial audit mission, formulating and supporting the audit opinion imply collecting audit evidence that must meet a series of requirements referring to the degree of appropriateness and sufficiency (Soltani). According to ISA 500 (IFAC, 2009), the degree of appropriateness concerns the measure of the quality of audit evidence, complying at the same time with the relevance and credibility criteria in justifying the conclusions on which the auditor's opinion is based. Additionally, the degree of sufficiency concerns the measure of the quantity of audit evidence, which is influenced by the auditor's evaluation of the risks of significant distortion, as well as by the quality of audit evidence (Pickett, 2006).
Hayes et al. (2005) consider that the financial auditor must evaluate the pertinence of the audit evidence associated with the procedures of testing certain statements: assertions concerning transaction categories and events associated with the audited period (occurrence, exhaustiveness, accuracy, separation of the fiscal years, classification), assertions concerning the accounts' balances at the end of the period (existence, rights and obligations, exhaustiveness, evaluation, and allocation) and assertions concerning information presentations and descriptions (occurrence and rights and obligations, exhaustiveness, classification and intelligibility, accuracy and evaluation).

Performing the audit mission, formulating and supporting the audit opinion imply collecting audit evidence that must comply with a series of requirements regarding the degree of appropriateness and sufficiency. The degree of appropriateness concerns the measure of the quality of audit evidence, meeting at the same time the pertinence and credibility criteria, in justifying the conclusions on which the auditor's opinion relies (Pickett, 2006). The degree of sufficiency concerns the measure of the quantity of audit evidence, which is influenced by the evaluation by the auditor of the risks of significant distortions, as well as by the quality of audit evidence (Pickett, 2006).

Based on the collected evidence, the financial auditor will come to know the audited company and its environment, the internal control system, and will detect the significant distortions at the assertions level (IFAC, 2009), reaching reasonable conclusions that will support the audit opinion. Hayes et al. (2005) present a series of techniques for collecting the audit evidence, used separately or combined within the mission: inspection, observation, external confirmation, recalculation, reexecution, analytical procedures and interrogation.

At the company level, during the financial audit mission, performing analytical procedures may represent one of the most efficient and reliable techniques for 
obtaining the evidence, both from the perspective of the minimum associated costs and from the perspective of the ease with which they can be applied. The data used may come either from the financial statements, or from financial diagnosis, stock exchange analysis or credit reports, already existent and authenticated (Soltani, 2003).

Arens and Loebbecke (2006) regard analytical procedures as an analysis of the main financial and trend ratios, including results on the investigations of the fluctuations and relations that are not in agreement with other relevant information of the same nature or that significantly differ from the forecasted data. We can draw the conclusion that analytical procedures imply using comparisons and relations in order to determine if the information synthesized in account statements or other data are reasonable, allowing the auditor to have an overview on the company's environment.

ISA 520 (IFAC, 2009) defines this concept as a set of evaluations of the financial information by analyzing the plausible relations between the financial and nonfinancial data. Moreover, analytical procedures include those investigations that meet the need to measure the fluctuations or relations that do not agree with other relevant information, or which differ by a significant amount from the expected values (Hayes, 2005). American standards, through SAS 56, correspond to the same definition formulated by ISA 520 , but stress the particularly important role played by the multiple regression analysis in order to obtain pertinent models in making comparisons at the branch or at the reporting period level, so that the financial auditor would be able to identify the unusual events or transactions, balance or business changes, random fluctuations or possible accounting distortions (Bragg, 2010).

The main purpose of the analytical procedures is to make comparisons and, if applicable, connections between the financial information of an entity and: information of the same nature for different time periods, anticipated results of the entity (budgets, forecasts, estimations of the auditor or estimations of amortization), information concerning a similar activity field (branch comparisons), financial information estimated to correspond to a predictable model (based on the company's experience) and other relevant financial and non-financial information (IFAC, 2009).

Connected to going concern, the analytical procedures applied in the preliminary stage of the mission aim at knowing the company, the activity area and the environment in which it performs its activity. This information is necessary for the financial auditor to accept the mission or not, to obtain context information, and to identify the risk areas. In this sense, Soltani (2003) gives special attention to the main financial indicators that characterize short-term solvency and liquidity, the ability to comply with the long-term obligations and to pay preferential dividends, which are indicators of operation and result.

Arens and Loebbecke (2006) believe that, during the audit mission, analytical procedures contribute significantly to obtaining supplementary data for understanding the economic field, for analyzing the activity of the audited company, and for evaluating its ability to preserve its activity (according to going concern), signaling at the same time any possible errors or fraud. Based on these procedures, Hayes et al. (2005) suggest making comparisons as follows: comparing the customer data with similar data prom previous years (comparing an account's balance in the current year with that in the previous year, comparing the details of a total, synthetic balance with similar details in the previous year, computing the indicators and relative measures and comparing them with the previous years, in order to identify possible errors), comparing the client's data with the results estimated by the client (planning, budgets), comparing the client's data with the results estimated by the auditor, comparing the client's data with the results estimated based on non-financial data. 
In the closing stage of the financial audit mission, which precedes issuing the opinion and the report, the financial auditor will collect the final evidence that will support their conclusions regarding the accuracy of the audited financial statements, evaluating at the same time the hypothesis of the going concern (Soltani, 2003).

Connected to specialized practice, Hayes et al. (2005) suggest a classification of the analytical procedures, as follows: trend analyses - comparisons of the fluctuations of the balance positions (comparisons at the level of historical, previous, and current periods), analyses at the level of the financial ratios - comparisons at the level of the relationships between the main balance positions, at the level of nonfinancial data, as well as comparisons at the level of activity field, reasonability analyses - represent a series of tests that aim to analyze the account balances or their changes within an accounting period, from the perspective of their reasonable nature and of the relationships between the accounts, data mining - computer-assisted auditing techniques (using a series of multiple regression statistical analyses, artificial intelligence techniques, for large sample volumes).

Although analytical procedures can provide, in general, pertinent and efficient clues in formulating the main conclusions that will support the opinion of the financial auditor, their main disadvantage may be the initial time consumption in drawing and preparing the testing models (mathematical models, algorithms, the knowledge base for expert systems). However, it is recommended to use them on large samples, at the level of the entire audited entity, and not on individual sections, in order to capture as faithfully as possible the significant aspects in the financial statements. Moreover, analytical procedures may be combined with other auditing procedures in order to obtain pertinent evidence and provide explanations for any possible differences identified.

\section{Research Methodology}

The present study aims to analyze and quantify the influence of financial and nonfinancial factors on the going concern of BSE quoted companies, in circumstances of economic and financial instability, by building mathematical models. Based on the parameters of the suggested models, financial auditors can use them as analytical procedures in their mission, in order to obtain audit evidence when they wish to analyze and study the clients' data in the context of the evolution of the financial market to which they relate. Normally, any deviations or unfavorable situations at the company level will have to be correlated to those of the market, and their study will also consider the influence of the economic and financial crisis in respect to the going concern assumption.

From a methodological perspective, this research follows a positivist approach that aims to test and validate a general hypothesis (made up of several work hypotheses) based on an illustrative (Smith, 2010). Last but not least, we also use a series of naturalistic principles specific to the interpretation approach, when we consider the analyzed issue and the way of generalizing it (by analyzing variables), the quality of the database and knowing the analyzed phenomenon (Lee et al., 2006).

Based on empirical evidence, combined with the usage of mainly quantitative data analysis methods, we have attempted to objectively illustrate the studied phenomenon (the incidence of insolvency on the going concern of the companies), resorting to a deductive-inductive reasoning (the particular determines the approach of the problem, and the validation of the work hypotheses is included in the general trend). 


\section{Developing the Work Hypotheses}

In the context of the recent economic and financial crisis, insolvency is characteristic to companies in difficulty, and in Webb's opinion (1991), among the determining factors we can mention the high production costs, insufficient liquidity, and last but not least, management strategies inappropriate for the economic reality. Also, the activity field, the sector or branch where the company performs its activity may enhance its predisposition to this fatal risk (Hayes et al., 2005), and in periods of economic crisis, the unfavorable state of the company may worsen, eventually leading to bankruptcy. A series of opinions claim that the risk of insolvency may also come from the funding method chosen by managers, as insolvency comes from high and very high values of the financial leverage (Penman, 2001). In what concerns the operational activity, Mironiuc (2006) presents a series of causes that may lie at the basis of the occurrence of the risk of insolvency: not achieving the production and sales plan, a higher fiscal pressure on the companies, insufficient own resources in comparison with the investments, the lack of liquidity, a higher pressure from creditors, an increase in the deadline for collecting the customers' debts. However, one of the problems that was not sufficiently discussed refers to the moment of occurrence of the risk of insolvency and to the period of survival of the company (the time while it can continue its activity), according to the evolution of the own economic and financial indicators, with the activity field taking as benchmark the date when the first BSE listing took place la. This way, we aim to test and validate the following work hypotheses:

H1: For the analyzed sample, the survival functions (from the date of BSE listing) of the companies subject to the risk of insolvency significantly differ between one another, in relation to the activity field and the suggested categories of consecrated financial ratios. This way, we aim to estimate the average survival time of the companies subject to the risk of insolvency, on each individual category (corresponding to the activity field or to the financial ratios), an information that is necessary to the financial auditor as audit evidence in the evaluation of the company's going concern.

H2: For the analyzed sample, it is possible to estimate the parameters of the survival functions of the companies subject to the risk of insolvency, using a series of financial (structure rations) and nonfinancial (activity field) factors. This way, we aim to determine (quantify) the influence of the considered variables on the probability to survive, as a mathematical model that can be used in the audit mission, in analytical procedures, in order to obtain audit evidence for supporting the final opinion.

\section{Target Population and Extracting the Analyzed Sample}

The target population that we wish to know is represented by Romanian companies quoted on the BSE. In this study, the work hypotheses were tested on a sample extracted randomly and stratified, according to the year when the quoted companies became insolvent, in the period 2008-2011.

Therefore, in 2008 of a total of 8 suspended companies, the insolvency procedure was started for 3 of them, in 2009 a number of 25 suspended companies was recorded (of which 14 insolvable companies), in 2010, 50 companies were suspended (36 insolvable), and in 2011, 71 suspended companies were recorded (of which 24 insolvable). Based on the number of companies that became insolvent in the period 2008-2011, the dimension of the analyzed sample has also been established (77 insolvable quoted companies).

Accompany to the activity field of the quoted companies, the structure of the analyzed sample is represented graphically in figure 1. 


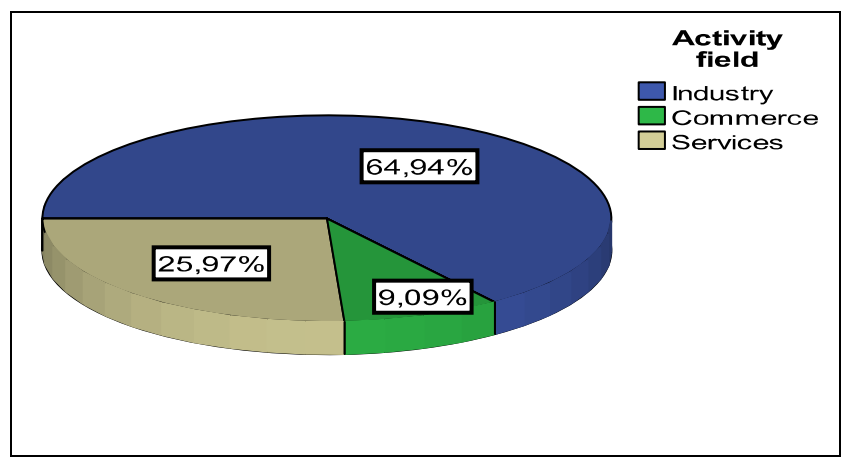

Figure 1. Structure of the Sample Extracted according to the Activity Field of the BSE Quoted Companies

(Source: Own Processing in SPSS 19.0)

We can notice that the companies have been divided into three main categories, according to their activity field: industry, commerce, and services.

\section{Analyzed Variables and Data Source}

In our study, in order to meet the research objectives by validating the work hypotheses, we have suggested a series of factor variables (activity field and consecrated financial ratios). Moreover, we have taken into account the influence of these variables for modeling the survival time and probability (result variables), using duration models. The variables considered in this study are synthesized in the table below:

Table 1. Analyzed Factor Variables

\begin{tabular}{|l|l|l|}
\hline Variables & \multicolumn{1}{|c|}{ Computing method } & \multicolumn{1}{c|}{ Meaning } \\
\hline RIA & $\left(\mathrm{A}_{\mathrm{i}} / \mathrm{A}_{\mathrm{t}}\right):$ Fixed assets/ Total assets & Asset immobilization ratio \\
\hline FL & $\left(\mathrm{D}_{\mathrm{t}} / \mathrm{C}_{\mathrm{pr}}\right):$ Total debt/ Shareholders' equity & Financial leverage \\
\hline TRC & $\left(\mathrm{C}_{\mathrm{c}} / \mathrm{CA}^{*} 360\right):$ Clients' debts / Sales figure * & $\begin{array}{l}\text { Deadline for collecting the clients' } \\
\text { debts (days) }\end{array}$ \\
\hline
\end{tabular}

(Source: Own Processing)

The influence of these factors on the survival probability and average time (since the beginning of the BSE listing) of the risk of insolvency can be determined only after discretizing the independent variables considered, taking into account the approach suggested by Jaba and Grama
(2004), in SPSS. The criteria used to obtain the considered categories are based on a series of references in specialized literature (Mironiuc, 2006 and Penman 2007). The new independent category variables are synthesized in Table 2 .

Table 2. Categories Obtained by Discretizing the Factor Variables

\begin{tabular}{|l|l|l|}
\hline Variables & \multicolumn{1}{|c|}{ Variable description } & \multicolumn{1}{c|}{ Categories on value intervals } \\
\hline Ctg_RIA & $\begin{array}{l}\text { Asset immobilization ratio } \\
\text { on categories }\end{array}$ & $\begin{array}{l}1-\text { RIA Low } \in[0 ; 0,5] ; 2-\text { RIA Average } \in(0,5 ; \\
0,75] ; 3-\text { RIA High } \in(0,75 ; 1) .\end{array}$ \\
\hline Ctg_FL & $\begin{array}{l}\text { Financial leverage on } \\
\text { categories }\end{array}$ & $\begin{array}{l}1-\text { FL Normal } \in[0 ; 2] ; 2-\text { FL Risky } \in(2 ; 4] ; 3-\text { FL } \\
\text { Critical } \in(-\infty ; 0) U(4 ;+\infty) .\end{array}$ \\
\hline Ctg_TRC & $\begin{array}{l}\text { Deadline for collecting the } \\
\text { clients' debts on categories }\end{array}$ & $\begin{array}{l}1-\text { TRC } \in[0 ; 45] ; 2-\text { TRC } \in(45 ; 90] ; 3 \\
\text { TRC } \in(90 ;+\infty)\end{array}$ \\
\hline
\end{tabular}


In order to determine the average survival time according to the considered (discrete) factors, as well as to quantify their influences on the probability to survive the risk of insolvency, the modeling will also take into account: the time elapsed since the beginning of the company's listing in BSE, the company's status at the end of the analyzed period (insolvable or not) and the activity field.

The data for the analyzed companies have been collected from the financial statements presented on the BSE website, corresponding to the fiscal years in the period 2008-2011.

\section{Data Analysis Based on Duration Models}

Determining the survival time of the companies, as well as estimating the influence of certain factors on the probability of occurrence of the risk of insolvency require the usage of duration models, based on the Kaplan-Meier estimator and of the Cox regression model. These models allow, at the same time, obtaining mortality tables (corresponding to the exposure to the risk of insolvency) applied to BSE quoted companies. The mortality table and the Kaplan-Meier estimator explain the life duration of companies according to their activity field, asset immobilization ratio, financial leverage, and deadline for collecting the clients' debts.

In order to evaluate risk of insolvency, we suggest using the survival function, $S(t)$, characterized by the Kaplan-Meier estimator, $\hat{S}\left(t_{i}\right)$. This function refers to the probability for a company to survive at the moment $\boldsymbol{t}$, the probability for it not to become insolvent until moment $\boldsymbol{t}$ (Jaba et al., 2012):

$$
S(t)=P(T>t)=1-F(t)=\int_{t}^{\infty} f(x) d x,
$$

, where:

$\boldsymbol{T}$ is the survival time or the duration until the moment when insolvency begins, and is a positive random variable; and $\boldsymbol{t}$ is a specified value for $\boldsymbol{T}$ (Jaba et al., 2011).The Kaplan-Meier estimator, $\hat{S}\left(t_{i}\right)$, can be defined, at different moments, $\mathbf{t}_{\mathbf{i}}$, as follows (Jaba et al., 2012):

$$
\hat{S}\left(t_{i}\right)=\prod_{t_{i-1} \leq t_{i}}\left(1-\hat{m}_{i}\right)
$$

, where:

$\hat{m}_{i}$ is the probability to become insolvent at the moment $t_{i}$,

$\left(1-\hat{m}_{i}\right)$ is the probability not to become insolvent (Kleinbaum and Klein 2005).

The graphical representation of the survival function can be made using the survival curve. This curve is built in a system of two orthogonal axes; on the abscissa, the $\boldsymbol{t}_{\boldsymbol{i}}$ moments (years) are represented, and on the ordinate, the probability to survive at the moment $\boldsymbol{t}_{i}$ when insolvency occurs is represented (Jaba et al., 2011).

In order to compare the probability to survive the risk of insolvency on groups of companies differentiated according to the activity field and levels of the considered financial indicators, the survival functions for the studied groups are compared, and the differences between them are tested using the Log-Rank test statistics (Jaba et al., 2012 ).

This test is obtained based on the formula: $U=\sum_{i}\left(O_{i}-E_{i}\right)$

, where:

$\boldsymbol{O}_{\boldsymbol{i}}$ - the number of (observed) companies that became insolvent;

$\boldsymbol{E}_{\boldsymbol{i}}$ - the estimated number of companies that may become insolvent (Allison, 2010).

The acceptance or rejection of the hypothesis of the concordance of the survival functions for the studied groups occurs after comparing the computed value of the $\log$-Rank test with the theoretical 
value of the Hi square statistic with ( $k$-1) degrees of freedom, where $\boldsymbol{k}$ is the number of groups (Jaba et al., 2011).

In order to estimate and test the influences of the activity field and of the levels of the considered financial indicators on the ris of insolvency, we suggest using the Cox model. The Cox model allows analyzing duration data, in the same way as regression models (Cox, 1972). The Cox can be used to estimate the hazard ratio, $\boldsymbol{h}(\boldsymbol{t})$, knowing the beginning of insolvency according to a linear combination of explanatory factors.

The hazard ratio can be defined, directly, as follows:

$h(t)=\left[h_{0}(t)\right] e^{b_{0}+b_{1} R I A+b_{2} F L+b_{3} T R C}$,

Or logarithmically,

$\ln h(t)=\ln h_{0}(t)+b_{0}+b_{1} R I A+b_{2} F L+b_{3} T R C$

, where:

$\boldsymbol{h}_{0}(t)$ is the reference hazard ratio (it has no specified parametric form); the hazard ratio when all the predictor variables equal 0 ; and $\boldsymbol{b}_{\boldsymbol{i}}$ are the regression coefficients (Allison, 2010).

The ratio of the hazard for companies in the sample to become insolvent during the analyzed period, under the influence of predictors (activity field and level of the considered financial indicators), can be estimated using the dedicated SPSS or SAS software.
The resulting outputs present the values of the hazard ratio, in different moments in time, the regression coefficients associated to the predictors and their degree of statistical significance.

The regression coefficients are also computed exponentially $\left(\boldsymbol{e}^{\boldsymbol{b}}\right.$, where " $\boldsymbol{e}$ " is the basis of the natural logarithm). The percentage modification of the hazard ratio, for a modification by one unit of the predictor variable, equals $100\left(e^{b}-1\right) \%$ (Jaba et al., 2011).

\section{Work Instruments}

Data analysis using duration models was based on the statistical software SPSS 19.0 and SAS Enterprise Guide 4.2.

\section{Research Results and Discussions}

After applying the duration models on the quoted companies in the analyzed sample, based on the data collected from the annual financial statements, a mortality table was drawn, corresponding to the risk of insolvency. This table includes a series of cells that present: the survival time until insolvency, on categories (from 0 to 15 years), the total number of companies that became insolvent at the beginning of each year of reporting to BSE, the number of companies that became insolvent each reporting year (since the first listing in BSE), the survival ratio of the risk of individual insolvency and of the risk cumulated in each year. The data obtained for the analyzed sample are synthesized in Table 3. 
Table 3. Mortality Table for BSE Quoted Companies Subject to the Risk of Insolvency

\begin{tabular}{|c|c|c|c|c|}
\hline $\begin{array}{c}\text { Interval } \\
\text { Start Time }\end{array}$ & $\begin{array}{c}\text { Number Entering } \\
\text { Interval }\end{array}$ & $\begin{array}{c}\text { Number } \\
\text { of events }\end{array}$ & $\begin{array}{c}\text { Proportion } \\
\text { Surviving }\end{array}$ & $\begin{array}{c}\text { Cumative Proportion } \\
\text { Surviving at End of Interval }\end{array}$ \\
\hline 0 & 77 & 0 & 1.00 & 1.00 \\
\hline 1 & 77 & 0 & 1.00 & 1.00 \\
\hline 2 & 77 & 0 & 1.00 & 1.00 \\
\hline 3 & 77 & 0 & 1.00 & 1.00 \\
\hline 4 & 77 & 0 & 1.00 & 1.00 \\
\hline 5 & 77 & 1 & 0.99 & 0.99 \\
\hline 6 & 76 & 0 & 1.00 & 0.99 \\
\hline 7 & 76 & 2 & 0.97 & 0.96 \\
\hline 8 & 74 & 0 & 1.00 & 0.96 \\
\hline 9 & 73 & 0 & 1.00 & 0.96 \\
\hline 10 & 73 & 0 & 1.00 & 0.95 \\
\hline 11 & 73 & 1 & 0.99 & 0.84 \\
\hline 12 & 72 & 8 & 0.89 & 0.47 \\
\hline 13 & 64 & 28 & 0.56 & 0.25 \\
\hline 14 & 35 & 13 & 0.54 & 0.25 \\
\hline 15 & 8 & 0 & 1.00 & \\
\hline
\end{tabular}

(Source: Own Processing In SPSS 19.0)

In Table 3 we can notice that at the beginning of BSE listing, no company was subject to the risk of insolvency, a situation that was preserved until the $5^{\text {th }}$ year of quotation. But at the end of the $5^{\text {th }}$ year, the first case of insolvency was recorded in the sample, so that only 76 of the 77 studied cases remained. We should mention that duration models continue analyzing the companies without those that were subject to this event in the previous period, in this case, becoming insolvent. Subsequently, based on the data presented in the mortality table, we can notice that for the immediately following period, the number of companies subject to the risk of insolvency was kept at a minimum level (close to 0), and the situation changed significantly for the companies that had been listed for at least 12 years in BSE. Therefore, after 12 years of listing, of a total of 72 companies left in the study, 8 became insolvent, insuring however a survival percentage of $89 \%$. We mention that the year of the first listing in BSE was 1996, for the analyzed sample, and the 12year period marks the beginning of the economic and financial crisis of 2008. However, a significant increase in the number of insolvent companies was recorded after 13 years of reporting (2009), with 28 signaled cases, which meant a survival percentage of 56\%. In 2010 (after 14 years of reporting), we can notice that the number of insolvent companies has reduced almost by half compared to 2009, which reflects the adaptation of the companies to the new conditions in the economic environment, as well as their relative improvement, thus insuring a survival percentage of $54 \%$ for the companies that remained in the study. Based on this data, we can draw the conclusion that the beginning of the economic and financial crisis had a disastrous impact on BSE quoted companies, especially for those with a lengthy activity.

According to the suggested work hypotheses, the impact of each analyzed factor variable on the probability to survive the risk of insolvency can be determined using the Kaplan-Meier estimator. 
Table 4. Survival Statistics for the BSE Quoted Companies B, on Activity Fields

\begin{tabular}{|l|c|c|c|c|}
\hline $\begin{array}{c}\text { Activity } \\
\text { field }\end{array}$ & $\begin{array}{c}\text { Number of } \\
\text { Companies }\end{array}$ & $\begin{array}{c}\text { No. Insolvent } \\
\text { Companies }\end{array}$ & $\begin{array}{c}\text { Survival } \\
\text { Percentage }\end{array}$ & $\begin{array}{c}\text { Average Survival } \\
\text { Time (years) }\end{array}$ \\
\hline Industry & 50 & 38 & $24.0 \%$ & 13.23 \\
\hline Commerce & 7 & 3 & $57.1 \%$ & 14.14 \\
\hline Services & 20 & 12 & $40.0 \%$ & 13.49 \\
\hline Global & 77 & 53 & $31.2 \%$ & 13.38 \\
\hline
\end{tabular}

The data in Table 4 indicate, for each analyzed activity field, the number of analyzed companies, the number of cases that became insolvent, and implicitly the survival percentage, and last but not least, the average survival time (in years). This way, we can notice that, for the analyzed sample, the smallest ratio of survival to the risk of insolvency has been recorded for companies in industry, of $24 \%$ (of 50 analyzed companies, 38 became insolvent), compared to the other two fields: services (40\% survival ratio) and commerce (57.1\% of the companies have not become insolvent). Combining this information with the average survival time, we can notice that companies in industry have recorded the highest number of insolvency cases and have been the least listed on BSE, only 13.23 years until being affected by this event, compared to the companies in the other two categories. The largest survival period (until insolvency) was recorded by companies in commerce (14.14 years), which succeeded in a ratio of $57.1 \%$ to continue their listing on BSE for 2010 as well.

The graphical representation of the survival function for the 15 years of BSE listing is stressed per activity field in figure 2. Based on the Log Rank test of the differences between the survival functions of the analyzed companies in each activity field, we can state with a probability of $80 \%$ that there are no significant differences between them. Therefore, the companies in commerce preserve $100 \%$ of the probability to survive up to 13 years of listing on BSE, compared to the companies in services, which register the first cases of insolvency 7 years after the first listing, and to those in industry, which register the first cases of insolvency only 5 after the first listing. At the same time, companies in commerce as well as those in industry have survival probabilities under $60 \%$ in 2009 (13 since the BSE listing), in this respect, the effects of the economic and financial crisis being fully felt by the BSE quoted companies.

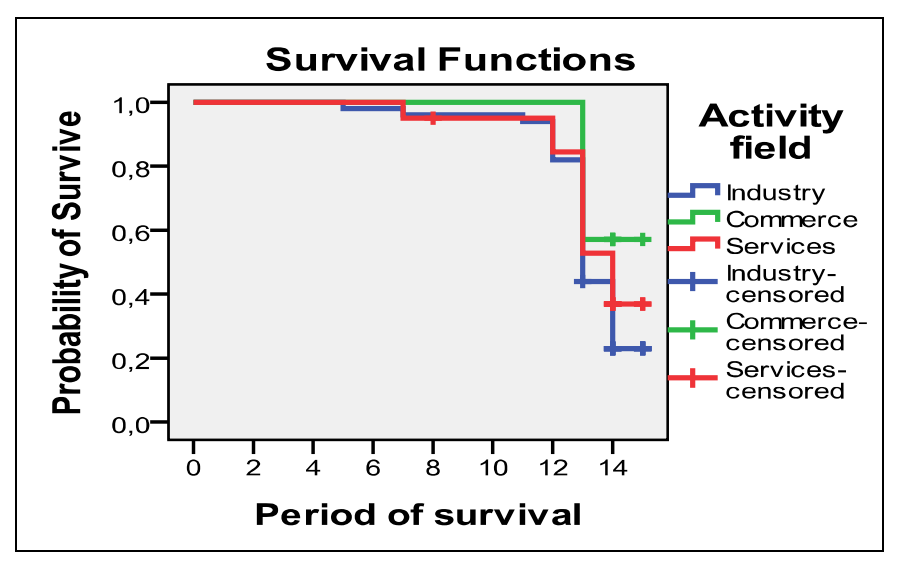

Figure 2. Survival Curves on Activity Fields

(Source: Own Processing in SPSS 19.0) 
Based on these data, the auditor can correlate the evolution of the financial position and performance of the audited client with those recorded at the market level, identifying any possible differences (reverse relations) or causes that lied at the basis of negative results, according to the activity field. At the same time, the auditor can also evaluate the impact of the economic and financial crisis on the period of going concern of the client, without the latter to become insolvent, according to the field in which the company operates.

The impact of the financial structure, as well as the destination of the financial resources corresponding to the studied companies on the probability to survive the risk of insolvency is presented in Table 5 and Table 6.

Table 5. Survival Statistics of the BSE Quoted Companies, according to the Asset Immobilization Ratio

\begin{tabular}{|l|c|c|c|c|}
\hline \multicolumn{1}{|c|}{ AIR } & $\begin{array}{c}\text { Number of } \\
\text { companies }\end{array}$ & $\begin{array}{c}\text { No. } \\
\text { Insolvent } \\
\text { Companies }\end{array}$ & $\begin{array}{c}\text { Survival } \\
\text { Percentage }\end{array}$ & $\begin{array}{c}\text { Average Survival } \\
\text { Time (years) }\end{array}$ \\
\hline Reduced & 23 & 14 & $39.1 \%$ & 13.08 \\
\hline Medium & 29 & 20 & $31.0 \%$ & 13.55 \\
\hline High & 25 & 19 & $24.0 \%$ & 13.48 \\
\hline Global & 77 & 53 & $31.2 \%$ & 13.38 \\
\hline
\end{tabular}

(Source: Own Processing in SPSS 19.0)

From the perspective of the immobilization ratio of the company's assets, we can state with a probability of $98 \%$ that the survival percentage for the BSE quoted companies with a low $A I R$ level is $39.1 \%$, compared to the companies with an average $(31.0 \%)$ or high (24\%) level. This way, we can notice that companies with a high AIR level have been the most subject to the risk of bankruptcy (for the analyzed sample, of 25 companies with FL High, became insolvent; the highest mortality ratio). With respect to the going period, we can state that companies with a high level of asset immobilization (between 0.5 and 0.75) have recorded the largest survival period (13.55 years), until becoming insolvent. This situation, influenced by the wa in which the resource destination criterion is met, in the funding process, reflects the vulnerability of the companies characterized by a high ratio of asset immobilization, towards the restrictions that exist in periods of economic instability.
Fixed assets diminish the company's solvency, because of their reduced ability to transform into liquidity, reducing, at the same time, the chances for a rapid adaptation to the changes in the business environment or even for a change in the activity field. This explains the situation of companies that perform their activity in industry and which have the lowest survival time and ratio. This way, the connection between the immobilization ratio in the total assets and the occurrence of the risk of insolvency is stressed, with an impact on the assumed premises of going concerned.

Monitoring this information, the financial auditor can have an overall image on the impact of the destination of the company's resources (own or foreign) on going concern. Moreover, the auditor can evaluate the need and opportunity for investments (as level of the total assets) on the company's going concern. 
Table 6. Survival Statistics of the BSE Quoted Companies, according to the Financial Ratio

\begin{tabular}{|l|c|c|c|c|}
\hline \multicolumn{1}{|c|}{ FL } & $\begin{array}{c}\text { Number of } \\
\text { companies }\end{array}$ & $\begin{array}{c}\text { No. Insolvent } \\
\text { Companies }\end{array}$ & $\begin{array}{c}\text { Survival } \\
\text { Percentage }\end{array}$ & $\begin{array}{c}\text { Average Survival } \\
\text { Time (years) }\end{array}$ \\
\hline Normal & 34 & 22 & $35.3 \%$ & 13.49 \\
\hline Risky & 9 & 7 & $22.2 \%$ & 13.56 \\
\hline Critical & 34 & 24 & $29.4 \%$ & 13.23 \\
\hline Global & 77 & 53 & $31.2 \%$ & 13.38 \\
\hline
\end{tabular}

(Source: Own Processing in SPSS 19.0)

The influence of the financial leverage on the average survival time and on the mortality ratio (insolvency) of BSE quoted companies is illustrated by the information in table 6. We can notice that companies with a normal indebtedness ratio, expressed by values of the financial leverage between 0 and 2 , have the highest survival ratio, $35.3 \%$ (of a total of 34 companies with a normal FL, only 22 became insolvent), compared to the companies with a Risky FL whose survival ratio is $22.2 \%$, or to those with a Critical FL that record a survival ratio of $29.4 \%$. Therefore, we can state that a correctly based usage of funding based both on own resources and on foreign resources is the main factor in preserving the going concern. In what concerns the average survival time, companies with a Critical FL have recorded the lowest duration of listing on BSE, the impact of the economic and financial crisis on them also determining their becoming insolvent after only 13.23 years of reporting according to
BSE (in full economic and financial crisis: the end of 2008 - the beginning of 2009).

Based on this information, the financial auditor can evaluate the average survival time, as well as the probability to become insolvent of a client that adopts a certain funding strategy de (stressed by levels of the financial leverage). All this is necessary for the auditor to evaluate the going concern ability, in conditions of a specific indebtedness ratio.

In the going concern evaluation, the auditor must take into account the management policy of the commercial relations of the audited company with its clients. The impact that the deadline for collecting the clients' debts has on the necessary of liquidity represents, in its turn, a trigger of the occurrence of the risk of insolvency. In this sense, table 7 presents a series of statistics regarding the average time of survival to the risk of insolvency, according to the various DDC levels.

Table 7. Survival Statistics of the BSE Quoted Companies, according to the Term for Collecting the Clients' Debts

\begin{tabular}{|l|c|c|c|c|}
\hline \multicolumn{1}{|c|}{ DDC } & $\begin{array}{c}\text { Number of } \\
\text { companies }\end{array}$ & $\begin{array}{c}\text { No. Insolvent } \\
\text { Companies }\end{array}$ & $\begin{array}{c}\text { Survival } \\
\text { Percentage }\end{array}$ & $\begin{array}{c}\text { Average Survival } \\
\text { Time (years) }\end{array}$ \\
\hline 0-45 Days & 21 & 12 & $42.9 \%$ & 13.91 \\
\hline 45-90 Days & 12 & 8 & $33.3 \%$ & 13.42 \\
\hline 90 + Days & 44 & 33 & $25.0 \%$ & 13.11 \\
\hline Global & 77 & 53 & $31.2 \%$ & 13.38 \\
\hline
\end{tabular}

(Source: Own Processing in SPSS 19.0)

Based on the data in the table above, we can state with a probability of $83 \%$ that the highest chance of survival, without becoming insolvent, is had by companies with the lowest deadline for collecting the client's debts, DDC values between 0 and 45 days insuring the company's going concern. Moreover, for a DDC between 0 
and 45 days, $42.9 \%$ companies that did not become insolvent have been recorded, this percentage being higher than those obtained by companies with a DDC between 45 and 90 days (33.3\%) and DDC over 90 days (25\%). In this respect, by collecting the client's debts, the company insures its necessary funding resources on the short term, as well as paying back its current debts. At the same time, we can also approximate the survival time (of going without becoming insolvent). Therefore, companies with a DDC between 0 and 45 days have the largest period of listing in BSE (without recording the presence of the risk of insolvency), of almost 14 years (13.91), compared to companies with a DDC over 90 days, whose average survival time is only au 13.11 years. In this case as well, the financial auditor can evaluate the company's ability to go, as well as the average survival time of the client, in the condition of the application of certain client management policies and of the delays for debt collection.
In order to punctually estimate the influence of the considered factor variables on the hazard ratio $\boldsymbol{h}(\mathbf{t})$, to know when companies become insolvent, we will use the Cox model, in which we will take into account the activity field of the analyzed companies as well. For this, we will use dummy variables corresponding to the activity field, having services as reference. The logic of dummy variables takes into account meeting or not the associated feature: if the company activates in industry, then $\mathrm{D}_{1}=1$, if not, $\mathrm{D}_{1}=0$. The same method is applied for companies in commerce. The form of the suggested model is presented below:

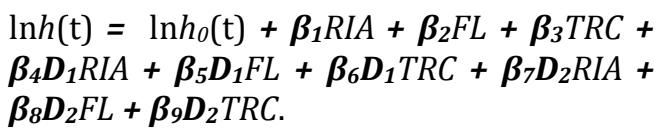

After estimating the coefficients of the Cox model in SPSS, the main results are synthesized in table 8.

Table 8. Parameters of the Suggested Cox Model, on Activity Fields

\begin{tabular}{|l|c|l|c|c|c|c|c|c|}
\hline \multicolumn{3}{|c|}{ Services } & \multicolumn{3}{c|}{ Industry } & \multicolumn{3}{c|}{ Commerce } \\
\hline \multicolumn{1}{|c|}{ Val. $\boldsymbol{\beta}$} & $\begin{array}{c}\text { Exp } \\
(\boldsymbol{\beta})\end{array}$ & Var. & Val. $\boldsymbol{\beta}$ & $\operatorname{Exp}(\boldsymbol{\beta})$ & Var. & Val. $\boldsymbol{\beta}$ & $\begin{array}{c}\text { Exp } \\
(\boldsymbol{\beta})\end{array}$ & Var. \\
\hline $\begin{array}{l}\boldsymbol{\beta}_{1}=- \\
0.707\end{array}$ & 0.493 & $R I A$ & $\boldsymbol{\beta}_{4}=0.648$ & 1.913 & $\boldsymbol{D}_{1} R I A$ & $\begin{array}{l}\boldsymbol{\beta}_{7}=- \\
0.766\end{array}$ & 0.465 & $\boldsymbol{D}_{2} R I A$ \\
\hline $\begin{array}{l}\boldsymbol{\beta}_{2}=- \\
0.010\end{array}$ & 0.990 & $F L$ & $\boldsymbol{\beta}_{5}=0.006$ & 1.006 & $\boldsymbol{D}_{1} F L$ & $\boldsymbol{\beta}_{8}=0.106$ & 1.111 & $\boldsymbol{D}_{2} F L$ \\
\hline $\boldsymbol{\beta}_{3}=0.001$ & 1.001 & $T R C$ & $\boldsymbol{\beta}_{6}=0.001$ & 1.001 & $\boldsymbol{D}_{1} T R C$ & $\boldsymbol{\beta}_{9}=0.001$ & 1.001 & $\boldsymbol{D}_{2} T R C$ \\
\hline
\end{tabular}

Based on the estimated results, we can state that for the analyzed sample, according to the companies' activity field, AIR has a significant impact on the chance for a company to become insolvent. For the companies in services and commerce, the connection is reversed, so that an increase by $1 \%$ of AIR determines a decrease by $50.7 \%$ RIA to become insolvent for the companies in services. At the level of the companies in industry, AIR determines an increase in the probability to be subject to the risk of insolvency, compared to those in services, so that for an increase by $1 \%$ of AIR, the insolvency risk will grow for the companies in industry, compared to those in services, by $91.3 \%$ (double risk), with an increase by $40.6 \%$ (91.3-50.7\%) per total. In the case of companies in commerce as well, we can notice that an increase by $1 \%$ of AIR will lead to a decrease by $53.5 \%$ of the probability to become insolvent, compared to the companies in services, with a decrease by $104.2 \%(50.7+53.5 \%)$ recorded per total. We can draw the conclusion that in the case of companies in services and commerce, an increase in the AIR determines a decrease of the probability to become insolvent, and in the case of companies in industry, the AIR 
increase favors the occurrence of insolvency (mainly on the account of the fixed assets that are not used in the operational activity).

An increase by $1 \%$ of the financial leverage (FL) determines, on the risk of insolvency of BSE quoted companies in the analyzed sample, a decrease by $10 \%$ in the probability to be subject to this event in the case of companies in services. For companies in industry, an increase by $1 \%$ of FL determines an increase of the chance to be subject to insolvency $0.6 \%$ higher than companies in services, with a total decrease of the probability to experience the event of $9.4 \%$ (10-0.6\%). In the case of companies in commerce as well, FL has a negative effect on the probability of occurrence of insolvency, so that an increase by $1 \%$ of FL determines a decrease in the risk of insolvency $11 \%$ higher than the probability recorded in the case of companies in services. We can conclude that an increase in the indebtedness ratio, expressed in FL values, can determine a decrease in the probability of occurrence of the risk of insolvency, in the conditions in which the foreign resources attracted follow the operational activity of the company, in order to keep it going.

Last but not least, analyzing the influence of the DDC variation on the companies' probability to become insolvent, we can notice that the effects of this indicator, according to the activity field, are relatively low, variations of $1 \%$ of DDC determining insignificant increases (by 1\%o) of the occurrence of the risk of insolvency. This demonstrates that the occurrence of the state of insolvency is rather related to the financing policies and to the mobilization policies of the attracted capital than to the commercial policies that the audited company applies in customer relations.

Moreover, the estimation of the coefficients in the Cox regression model can provide, as analytical procedure, audit evidence concerning the company's ability to continue as a going concern, according to punctual values of the considered factor variables.

\section{Conclusions and Future Research}

In the audit mission, the financial auditor has the responsibility to express an objective, independent, and professional opinion on the accuracy of the reported financial information in relation to the imposed accounting reference. Moreover, the auditor must take into account the extent to which the audited company can continue its activity within a predictable time horizon, without becoming insolvent, which affects the accuracy of reporting.

Therefore, it is required to use the best audit evidence that will support the final audit opinion, which are obtained through analytical procedures that resort to advanced methods of quantitative analysis.

After validating the two suggested work hypotheses, we can state that by using duration models and obtaining the mortality tables, the auditor will be able to estimate punctually, after each year of listing with BSE, the probability for the audited company to become insolvent or not. Then, according to the evolution of the market as well as to the activity field of the audited company, the auditor will be able to estimate the survival period until insolvency. As reflected by empirical results, the survival period may vary according to a series of non-financial (activity field) and financial factors: structure ratios of the balance assets and liabilities, or DDC).

Last but not least, in evaluating the correct usage and financial reporting according to the going concern, the auditor may correlate data regarding the evolution and status of the market (including on branches and activity fields) with the client's data, in order to identify any differences or to explain the current status of the audited company, based on a certain general trend.

Based on the obtained results, the auditor may gain an overview on the company's environment, on its financial structure, on the destination of its resources, and on its commercial policies. Therefore, using duration models in the audit mission may determine the auditor to obtain sufficient 
and appropriate information that would support their opinion in the audit report.

Future directions of the study concern including other (financial and non-financial) influence factors into the analysis, as well as developing the mortality tables on each individual activity field.

In what concerns the limitations, the study stops at the level of occurrence of insolvency in a period of economic and financial crisis (2008-2011), but this interval can be extended in future studies.

Last but not least, using statistical methods in the financial audit mission, as well as interconnecting their results with financial analysis and accounting may open a new research direction. This new field that aims to analyze the economic and financial phenomena in financial audit based on financial analysis indicators through advanced statistical and econometric methods is hypothetically called auditometrics.

\section{Acknowledgements}

This work was supported by the European Social Fund in Romania, under the responsibility of the Managing Authority for the Sectoral Operational Programme for Human Resources Development 20072013 [grant POSDRU/CPP 107/DMI 1.5/S/78342].

\section{References}

Allison, P. D. (2010). Survival Analysis Using SAS: a Practical Guide, 2nd edition, SAS Publishing, North Carolina.

Arens, A., Loebbecke, J. (2006). 'Audit o Abordare Integrată,' Ed. Arc, Chişinău.

Bandyopadhyay, A. (2006). "Predicting Probability of Default of Indian Corporate Bonds: Logistic and Z-Score Model Approaches," The Journal of Risk Finance, Vol. 7, No. 3, Pp. 255-272.
Bessell, M., Anandarajan, A. \& Umar, A. (2003). "Information Content, Audit Reports and Going-Concern: An Australian Study," Accounting and Finance, 43, 261282.

Bhimani, A., Gulamhussen, M. A. \& Lopes, S. (2009). "The Effectiveness of the Auditor's Going-Concern Evaluation as an External Governance Mechanism: Evidence from Loan Defaults," The International Journal of Accounting, 44, 239-255.

Bragg, S. M. (2010). Practitioner's Guide to GAAS 2010: Covering all SASs, SSAEs, SSARSs, and Interpretations, John Wiley \& Sons, New Jersey, 2010, Pp. 163-165.

Braiotta, L. Jr., Gazzaway, R. T., Colson, R. \& Ramamoorti, S. (2010). The Audit Committee Handbook, Fifth Edition, John Wiley \& Sons, New Jersey.

Chitnomrath, T., Evans, R. \& Christopher, T. (2011). "Corporate Governance and PostBankruptcy Reorganization Performance," Asian Review of Accounting, Vol. 19, No. 1, Pp. 50-67.

Cox, D. R. (1972). "Regression Models and Life Tables," Journal of the Royal Statistical Society, Vol. 34(2), Pp. 187-202.

Eleni Vrentzou (2011). "The Effects of International Financial Reporting Standards on the Notes of Auditors," Managerial Finance, Vol. 37 Iss: 4, Pp.334 346.

Elliot, R. S., Highfield, M. J. \& Schaub, M. (2006). "Contagion or Competition: GoingConcern Audit Opinions for Real Estate Firms," Journal of Real Estate Finan Econ, $32,435-448$.

Franks, J. R. \& Lóránth, G. (2010). “A Study of Inefficient Going Concerns in Bankruptcy," www.cepr.org/pubs/dps/DP5035.asp, Accessed on 20.06.2011. 
Hayes, R., Dassen, R., Schilder, A. \& Wallage, P. (2005). Principles of Auditing. An Introduction to International Standards of Auditing, Second Edition, Ed. Pearson Education.

Herbohn, K., Ragunathan, V. \& Garsden, R. (2007). "The Horse has Bolted: Revisiting the Market Reaction to Going Concern Modifications of Audit Reports," Accounting and Finance, 47, 473-493.

International Accounting Standards Board (2009). Standardele Internaţionale de Raportare Financiară (IFRS), Ed. CECCAR, București.

International Federation of Accountants (2009). International Standards on Auditing, New York.

Jaba, E. \& Grama, A. (2004). 'Analiza Statistică Cu SPSS Sub Windows,' Ed. Polirom, Iaşi.

Jaba, E., Balan, C.- B., Robu, I.- B. \& Roman, M. (2012). 'Statistical Evaluation of the Fraud Risk in Order to Base the Audit Opinion, Using Duration Models,' Financial Audit Journal, No. 10(4), Pp. 14-23.

Jaba, E., Robu, I. B. \& Balan, C. B. (2011). 'Financial Fraud Risk Assessment, by Activities, Using Statistical Analysis of the Factors to Base the Audit Opinion,' In Proceedings of the International Conference on Economic Cybernetic Analysis: Global Crisis Effects and the Patterns of Economic Recovery GCER-2011, Pp. 220-232.

Kausar, A., Taffler, R. J. \& Tan, C. (2009). "The Going-Concern Market Anomaly," Journal of Accounting Research, 47/2009 (1), 213-239.

Kleinbaum, D. \& Klein, M. (2005). 'Survival Analysis: A Self-Learning Text,' 2nd Edition, Springer, New York.

Krause, A. (2006). "Risk, Capital Requirements, and the Asset Structure of Companies," Managerial Finance, Vol. 32, No. 9, Pp. 774-785.
Liou, F.- M. \& Yang, C.- H. (2008). "Predicting Business Failure under the Existence of Fraudulent Financial Reporting," International Journal of Accounting and Information Management, Vol. 16, No. 1, Pp. 74-86.

Lye, J., Perara, H. \& Rahman, A. (2006). Grounded Theory: A Theory Discovery Method for Accounting Research, Published In: Hoque, Z. (2006), Methodological Issues in Accounting Research: Theories and Methods, Spiramus Press, London.

Matsumara, E. M., Subramanyam, K. R. \& Tucker, R. R. (1997). "Strategic Auditor Behavior and Going-Concern Decisions," Journal of Business Finance and Accounting, 24 (6), 727-758.

Mironiuc, M. (2006). Analiză EconomicoFinanciară. Elemente TeoreticoMetodologice Şi Aplicaţii, Sedcom Libris, Iaşi.

Ooghe, H. \& De Prijcker, S. (2008). "Failure Processes and Causes of Company Bankruptcy: A Typology," Management Decision, Vol. 46, No. 2, Pp. 223-242.

Penman, S. H. (2007). Financial Statement Analysis and Security Valuation, 3rd Edition, Mcgraw Hill.

Philosophov, L. V. \& Philosophov, V. L. (2005). “Optimization of a Firm's Capital Structure: A Quantitative Approach Based on a Probabilistic Prognosis of Risk and Time of Bankruptcy," International Review of Financial Analysis, Vol. 14, Pp. 191-209.

Pickett, K. H. S. (2006). Audit Planning: A Risk-Based Approach, John Wiley \& Sons Inc, New Jersey.

Porter, B., Simon, J. \& Hatherley, D. (2003). Principles of External Auditing, Second Edition, John Willey \& Sons LTD, West Sussex, 2003.

Schroeder, S. (2009). "Defining and Detecting Financial Fragility: New Zealand's Experience," International Journal of Social Economics, Vol. 36 No. 3, Pp. 287-307. 
Soltani, B. (2003). 'Auditing: An International Approach,' Prentice Hall, Pearson Education, Essex.

Uang, J. Y., Citron, D. B., Sudarsanam, S. \& Taffler, R. J. (2006). "Management GoingConcern Disclosures: Impact of Corporate Governance and Auditor Reputation," European Financial Management, 12 (5), 789-816.

Webb. D. (1991). “An Economic Evaluation of Insolvency Procedures in the United Kingdom: Does The 1986 Insolvency Act Satisfy the Creditors' Bargain?," Oxford Economic Papers, 43, Pp. 139-157.

Zaher, T. S. (2010). "Performance of Debt Free Firms," Managerial Finance, Vol. 36, No. 6, Pp. 491-501. 